Millatī, Journal of Islamic Studies and Humanities

Vol. 5, No. 1, June 2020: p. 34-50. DOI: 10.18326/mlt.v5i1. 34-50

p-ISSN : 2541-3627 ; e-ISSN 2540-9964

Website: http://millati.iainsalatiga.ac.id/index.php/millati/index

\title{
Democratic Political Contestation: State, Islam and Media in Indonesia's Reformative Era
}

\author{
Siti Mutiah Setiawati \\ Universitas Gajah Mada Yogyakarta, Indonesia \\ smutiab@ugm.ac.id
}

\begin{abstract}
On December 2, 2018 millions of Muslims throughout the country came together in Jakarta and met in the very heart of Indonesian capital city the National Monument and surroundings (Monas). This is not the first as at least two similar events which are famously known as 212 and 411 events had occurred before, also at the same place. Although, the meeting was attended by prominent figures of religious leaders, from the speeches, symbols, as well as messages sent publicly it was more appropriate to be called a political event based on religious sentiments rather than religious meetings or rites. The ultimate goal of the meeting is, quite probably, to put political pressure on the regime. Accordingly, what they expected that such a big political event was covered by mass Media and exposed worldwide. Meanwhile, the mass media has been reluctant to make such coverage. In response to the unusual political behavior of media, the Muslims of those in favor of putting political pressure against the regime tend to optimize the use of social media which is more difficult to be controlled. This paper aims to describe the phenomenon of Indonesian political communication, the relationship pattern between Media, State, and Islamic Community, and also to answer why Indonesian Media become one-sided behavior just before the national election that is popular called "democratic fiesta" happened. The research method includes qualitative research, namely specific primary data collected through library research, then interpreted to find generalizations. Interviews with experts were conducted to analyze specific cases.
\end{abstract}

Keywords: Indonesia, Islam, Communication, Politics, Democracy.

\begin{abstract}
Abstrak
Pada 2 Desember 2018 jutaan Muslim di seluruh negeri berkumpul di Jakarta dan bertemu di jantung ibu kota Indonesia, Monumen Nasional dan sekitarnya (Monas). Ini bukan yang pertama karena setidaknya dua peristiwa serupa yang dikenal sebagai peristiwa 212 dan 411 pernah terjadi sebelumnya, juga di tempat yang sama. Meskipun, pertemuan itu dihadiri oleh tokoh-tokoh pemimpin agama terkemuka, dari pidato, simbol, dan pesan yang dikirim ke publik, lebih tepat disebut sebagai acara politik yang berdasarkan sentimen keagamaan daripada pertemuan atau ritual keagamaan. Tujuan akhir dari pertemuan tersebut adalah, sangat mungkin, untuk memberikan tekanan politik pada rezim. Dengan demikian, apa yang mereka harapkan bahwa peristiwa politik sebesar itu diliput oleh media massa dan diekspos di seluruh dunia. Sementara itu, media massa telah enggan untuk membuat liputan tersebut. Menanggapi perilaku politik media yang tidak biasa, umat Islam yang mendukung tekanan politik terhadap rezim cenderung mengoptimalkan penggunaan media sosial yang lebih sulit dikendalikan. Artikel ini bertujuan untuk menggambarkan fenomena komunikasi politik Indonesia, pola hubungan antara Media, Negara, dan Komunitas Islam, dan juga untuk menjawab mengapa
\end{abstract}


Media Indonesia menjadi perilaku satu sisi sesaat sebelum pemilihan nasional yang populer disebut "demokratis pesta" terjadi . Metode penelitian meliputi penelitian kualitatif, yaitu data primer spesifik yang dikumpulkan melalui penelitian kepustakaan, kemudian ditafsirkan untuk menemukan generalisasi. Wawancara dengan para ahli dilakukan untuk menganalisis kasuskasus tertentu.

Kata kunci: Indonesia, Islam, Komunikasi, Politik, Demokrasi.

\section{INTRODUCTION}

This article was inspired by an event on December 2, 2018, when millions of Muslims dressed in white gathered at the same place, the national monument (Monas) in Jakarta. Their purpose of gathering peacefully in the center of the Capital of the Republic of Indonesia was to communicate with the Indonesian government and public in response to accusations that the Islamic community would change the ideology of the Pancasila state, change the form of the Republic of Indonesia, and be intolerant to other religions. This activity included a peaceful demonstration which was an extraordinary event because it involved millions of people without any violence. However, this activity was not covered by the mass media both electronic and printed media, only one television that broadcasts that is TV One and one Republika / Newspaper/ printed media. There is a possibility that there is an agreement by Media Indonesia not to cover this political phenomenon.

Not covering major events can be read as a phenomenon that; First, Media Indonesia has violated the principle of the function of the media as a bridge between the people and the state which must be neutral or impartial if there are differences in interests between the two. Secondly, Media Indonesia has been controlled by the authorities so that it only reports in favor of the government and will not cover news that is considered to endanger the government's position. As a result, Indonesian media have lost their function as a tool to control the government. Third, Media Indonesia considers that reporting about the gathering of millions of people at a time, in the same place would jeopardize the integration of the nation. Fourth, Media Indonesia hampers the process of political communication from the public to the government, which means it can hamper the post-reform democratization process. Fifth, there is a lack of harmonization of relations between the government and certain Muslim communities, considering that the action was an act of Muslims. 
Millatī, Journal of Islamic Studies and Humanities, Vol. 5, No. 1, June 2020: 34-50

The tendency of the government to dominate more political communication has been shown since the early days of independence the aim was to gain popular support in the country's resistance against the Dutch who wanted to re-colonize Indonesia. Slogans such as "Freedom or Death" are often heard by the people to encourage them. While in the days of President Suharto the people were often given input about the latent danger of Communism ideology that must be watched out. The experience of the two orders, namely the Old Order and the New Order, media was too dominated by the state, which hampered the process of democratization because people's political participation was low.

Indonesia entered the Reform Order, which was marked by the downfall of President Suharto, who had been in power for 35 years in May 1998. President Suharto's one-way political communication style that did not give freedom to the media changed completely when President Habibi as vice-president succeeded him. The first thing done by Habibi is to guarantee the freedom of the press or media as a characteristic of a democratic country. In the reformation era, people feel the freedom of the media so that the atmosphere of communication between the government and the community and between the people and the government is smooth and harmonious. This tradition was continued by Habibie's successors namely President Abdurrahman Wahid, Megawati Sukarno Putri, Susilo Bambang Yudhoyono (SBY I \& 2) to President Joko Widodo (Jokowi).

At first, Jokowi did not object to the communication style of gathering in large numbers in one place, this was evidenced in his presence at a similar action before. The 212 reunions on 2 December 2018 was preceded by similar actions, namely the Islamic Defendant Action I (First) which was chaired by the Islamic Defender Front (FPI ) Habib Rizieq on 14 October 2016, Islamic Defendant Act II 4 November 2016, and Islamic Defendant Action III which was chaired by the leader of the Movement National Guard of Fatwa MUI (Indonesian Ulema Council), Bachtiar Nasir. President Jokowi was willing to attend the 212 actions in 2016.

Among the Actions, there were those who demanded that Ahok or Basuki Tjahaya Purnama, non-Muslims of Chinese descent who at that time became the Governor of the Jakarta Special Capital Region is criminalized for insulting Islam. Ahok has insulted the Alquran especially Surah Al Maidah verse 51 which prohibits a Muslim from choosing nonMuslim leaders to be used by Islamic leaders to achieve their political goals. As a result of these actions, Ahok was decided to be a suspect on November 16, and on May 9, 2017, Ahok had to 
serve a sentence of 2 years. In addition, Ahok also lost the re-nomination as Governor of Jakarta in 2017 from Anies Basewedan-Sandiaga Uno. Actions that demanded that Ahok be covered in full by the mass media both print and electronic, most of the media covered comprehensively, and attracted the attention of the audience.

Based on this experience that the media can spread the message quickly so that the political demands of community groups can be achieved, then Jokowi is not only not present at the 212/2018 Reunion Action event but also possibly encouraging the media not to cover it for the sake of political stability for the country. Public opinion is divided between those who are not informed and those who condemn major events that deserve the attention of the public to be reported but not reported as the nature of government injustice. At the same time government concerns that the 212 Reunion Act could displace the President's leadership.

The purpose of this paper will be to discuss new trends in political communication in Indonesia from communication dominated by the government in socializing political programs, to communication that is dominated by the public to communicate their political attitudes to the government. Previously, the government used mass media to socialize its programs, so when the community would communicate their interests, Indonesian Mass Media did not provide the same opportunity. The second objective of this article will describe the relationship between democracy and political communication that takes place between the State, Mass Media, and Society (Islam) in Indonesia.

From the background of the problem and the purpose of the writing, the following questions can be formulated: What is the pattern of Indonesian political communication during the reform era, namely the relationship between the state, the media, and the community, especially the Islamic community as the majority of the population of approximately 276 million. The extent of the role of the Indonesian media in conveying the political socialization of the government to the public and conveying the interests of the community to the government. The next question is why the mass media is not willing to cover a major event involving the wider community on December 2, 2018 ?

\section{METHODS}

The method used in this study is a qualitative method that is a method that emphasizes more in-depth interpretation of the Main Data in research which includes: Indonesian Political 
Millatī, Journal of Islamic Studies and Humanities, Vol. 5, No. 1, June 2020: 34-50

Communication Reform Era, 212 Movement, Indonesian Mass Media, and the Indonesian Political System to get a picture of the development of the relationship pattern so that it can be used to analyze why the media does not cover an event that is included in the news. In the qualitative method, it also emphasizes identity politics, that the Islamic identity brought by the 212 Movement is opposite the rulers who have a more secular identity.

\section{Theoritical Framework}

Political communication can be defined as messages about government policies to the people to get support from the community, and messages from the public about the interests that must be accommodated by the government in a political system. The flow of communication can be described as follows:

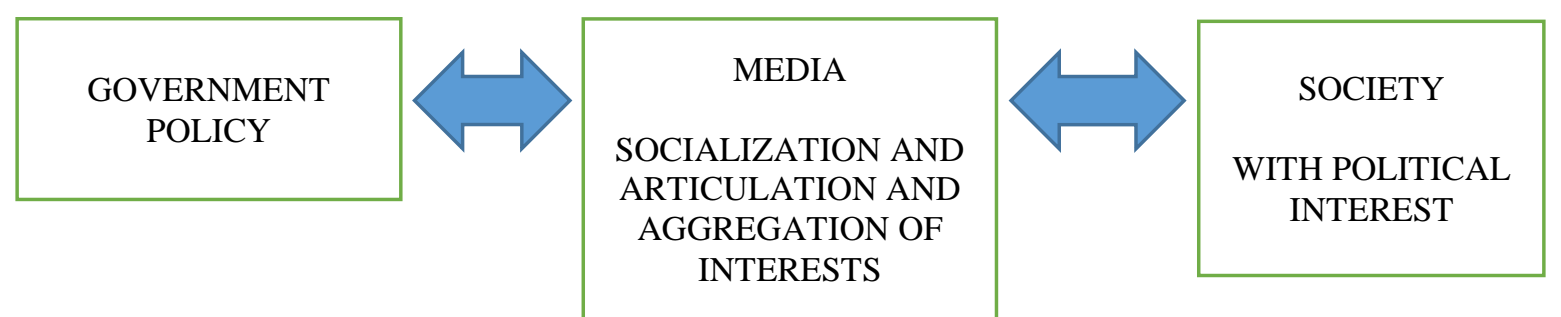

According to Brain Mc Nair political communication is defined as purposeful communication about politics, this incorporates: (1). all forms of communication undertaken by politicians and other political actors to achieve specific objectives; (2). communication addressed to these actors by non-politician such as voters and newspaper columnist; and (3). communication about these actors and their activities as contained is new reports, editorials or other forms of media discussion of politics ${ }^{1}$.

Nair's writing clarifies the writer's opinion on the definition and description of what is meant by political communication, and how the process of political communication in a political system. This book can also be used to describe the patterns of Indonesian political communication in the reform era by describing all forms of communication between politicians and non-politicians to achieve certain goals.

Gadi Wolfsfeld in his book Media \& Politics, Five Principles in Political Communication states that there are 5 (five) principles in political communication; First, those without political power

\footnotetext{
${ }^{1}$ Brian Mc Nair, An Introduction to Political Community (London, New York: Routledge, 2011), p. 4.
} 
find themselves very difficult regarding the news. Political power can usually be translated into power over the new media; Second, when the authorities lose control over the political environment they also lose control over the news; Third, the news media is played in attempts to buy an end to the conflict. There is no such thing as objective journalism nor can there be. Fourth, turning politics into news. The media are dedicated more than anything else to tell a good story and this can often have a major impact on the political process. Fifth, the most important effects of the news media on citizens tend to be unintentional and unnoticed ${ }^{2}$. The author is very inspired by this book because the 5 (five) principles in political communication described in this book can be the basis of the argument why the media refuses to broadcast events that have great news value, while one of the tasks of the media is to change political issues to become news.

Indonesian Political Communication Patterns of the Reformation Period: The Dynamics of Islamic Community - State Relations

Since the beginning of independence, the political communication of Islamic groups with the state has experienced tidal dynamics. This is possible because although Muslims are very instrumental in Indonesia's state-building, the heterogeneity of the Islamic community with different background interests makes it difficult for the country to accommodate all. Apart from that, sometimes the state does not treat all groups equally so that dissatisfaction of other groups arises which ultimately hinders communication with the government. The purpose of this chapter is to describe the pattern of political communication between the state and the Islamic community and how the attitude of the media in bridging communication between the two, and how the role of the media as a means of control over government performance.

Historically Indonesia's political format is very much influenced by Islamic political thought and support. The Declaration of Independence of 17 August 1945, the preamble, as well as the body of thoughts of the Constitution (Undang-Undang Dasar 1945) are in support of this statement. Ironically, however, in the continuing history after independence instead of being explored for the benefit of the country, Islamic political power has been prevented from winning the political contestations by the authority, marginalized, and even put into a corner.

${ }^{2}$ Gadi Wolfsfeld, Making Sense of Media \& Politics : Five Principles in Political Communication (New York: Routledge, 2011), p. 3. 
Millatī, Journal of Islamic Studies and Humanities, Vol. 5, No. 1, June 2020: 34-50

In doing so, Islamic political parties who opposed the authority were emasculated or even banned. Meanwhile, prominent Islamic leaders were threatened with imprisonment or prohibited from playing a political role. This short story roughly illustrates the whole story of state - Islam relations after Indonesia's independence. Soekarno, the first president is known for his discontent and politically motivated attack to Buya Hamka, a great Indonesia Islamic leader, for his opposition to the political ideology of the president. Further, in 1964, President Soekarno imprisoned Hamka for 2 years and 4 months without due process of law. The contentious relations between the two eventually ended when the power of President Soekarno dimed. The relations between the State and Islam in Soeharto's era and the era of five following presidents' shares similarity in the pattern. Accordingly, the above story in simplicity describes the relationship pattern between the State and Islam throughout. Before achieving sovereignty of independence, Islam has become a crash-bumper, the spearhead, and base of legitimacy for the president, while post-sovereignty achievement demonstrates that the relationship between the two has dramatically changed. Islam was no longer perceived as a friend but rather as "foe", deemed as a threat to the legitimacy of the then ruling President.

Furthermore, this research will look at the relationship between the government and the Islamic community through the periodic leadership of the President. President Soekarno as President I of Indonesia had to face many domestic and foreign problems, especially regarding the backwardness of Indonesian people in all fields, poverty, tropical diseases that were still suffered by the people at that time, and the parliamentary cabinet that was easily dissolved so that domestic politics became unstable. President Soekarno took advantage of the divisions among Indonesian Muslims between two big Islamic organizations, NU (Nahdatul Ulama) and Muhammadiyyah by dissolving or issuing a ban on Muhammdiyyah's Party namely Masyumi so that NU became very close to the authorities. While Muhammadiyah became an Islamic organization that had an unharmonious relationship.

In general, it can be said that the relationship between the state and Islam in Indonesia experienced ups and downs. Although the Indonesian government has consistently maintained good relations with Islamic countries especially in the Middle East, it has not always been consistent in maintaining good relations with the Islamic community in Indonesia. An unharmonious relationship between the government and the Islamic community will affect domestic political stability while at the same time harming the Islamic community because they 
can lose the opportunity to take a role in politics. This tendency is evident in the government of the Second President, Suharto.

During the reformation period after President Suharto stepped down, the relationship between Islam and the government did not experience significant and worsening changes. However, under President Jokowi, Islamic groups if they did not support all government programs, would be labeled as radical, anti-pluralism, and anti-state ideology of Pancasila or even intolerance religion. On the other hand, Indonesia's foreign relations with Islamic countries remain warm and harmonized as shown: Indonesia's support for Palestine, establishing the Special Consulate General's office in Ramalah, condemning Israeli attacks in the Gaza Strip, actively attending sessions of Islamic Cooperation Organizations, and offering themselves as the mediator in Afghanistan's internal conflict.

Through some understanding of the elements of political communication, we will discuss what the function of political communication is, especially if we look at its application in the political system in Indonesia. Political communication is a part of the political system according to the political system chart created by Gabriel Almond. Together with Political Socialization and Recruitment, Interest-articulation, interest aggregation, political communication is part of an "input" in the political system. The results after processing will be in the form of Rulemaking, Rule application, and Rule adjudication. In an ideal democratic system, the state gives freedom to political communication to carry out its function as an articulation of the interests and aggregation of people's interests. So that, political communication can also be defined as communication involving political massages and political actors, and it associates with power, governing, and government policy. In the ideal type of democracy, the government provides political communication freedom to the people to articulate and aggregate their interest to the government.

From the First President of Indonesia, it seems that the Media has carried out functions of political communication well in different ways. President Joko Widodo initially also implemented those functions well. However, when his political position was threatened by peaceful demonstrations with a fantastic number of approximately 13.5 million people gathered at the heart of the capital city Jakarta, Jokowi injured the function of political communication by ignoring the functions of articulation and aggregation of interests and wanted to advance the political image. This policy is of course detrimental to people who want 
Millatī, Journal of Islamic Studies and Humanities, Vol. 5, No. 1, June 2020: 34-50

complete coverage of phenomenal political events such as the events of December 2018. For Islamic societies who use the opportunity of the openness of the political system to express their aspirations, the attitude of the media that does not broadcast this event means that it has blocked the delivery of their interests to the government.

\section{Failure in Building Harmonious Political Communication}

Since its inception of Independence, the government of the Republic of Indonesia has failed in building harmonious political communication between the government towards the people of Indonesia, especially with the Islamic community. The failure of harmonious political communication is caused by at least four factors: First, an authoritarian system of government when the power of the President is very strong because of a presidential system that does not allow a President to be overthrown by Parliament. Secondly, the Government does not articulate the interests of Muslims which vary greatly even though they are most of Indonesia's population. Third, almost all mass media are controlled by the government or owned by entrepreneurs who are close to the government. As a result, community interests are not well communicated. Fourth, the government doesn't provide a clear and detailed policy as well as not explaining and interpreting the regulation and existing government policies so that people have well informed and understood the government's policy. The following issues will be discussed one by one so that answers will be obtained as to why political communication in Indonesia is hampered and the big news is not covered by the vast majority of Indonesian Media.

The quality of Indonesian Democracy during Jokowi's leadership declined especially towards the end of his first term and the 2019 election $^{3}$. When compared with the President of the Reformation period, Jokowi was the most failed President in delivering political communication with the Indonesian Muslim community.

Indonesian Muslims are very heterogeneous in terms of schools, organizations, sects, attitudes towards government, and others. From an organizational perspective, there are two large organizations when viewed from the number of memberships, Nahdatul Ulama (NU)

\footnotetext{
3 Thomas P. Power, “Jokowi's Authoritarian Turn and Indonesia's Democratic Decline”, Bulletin of Indonesian Economic Studies, Vol. 54, Issue 3, (2018): p. 307-338, https://www.tandfonline.com/doi/abs/10.1080/00074918.2018.1549918?journalCode=cbie20.
} 
and Muhammadiyyah. These two Islamic organizations are not political organizations but religious social organizations that govern social, economic, and educational needs for the wider community. Muhammadiyyah was founded in 1912, and Nahdatul Ulama in 1926. During the Reformation period after the second President, Suharto stepped down because he was revealed by students in 1998, an Islamic organization called the Islamic Defenders Front (FPI), led by Habib Rizieq, an Arab descent emerged.

FPI, the relatively new Islamic movement was accompanied by the National Movement for Guarding the Fatwa of the Indonesian Ulema Council (GNPF-MUI) which had the initiative to carry out political communication with the government so that Ahok be tried by peaceful assembly with a white dress code. The idea to gather peacefully was supported by many people from all elements of Islam. It was suspected that hundreds of thousands or even millions of people had gathered since morning for the Fajr prayer on December 2, 2016, so that the Movement was called 212. Presidents Jokowi, and Ma'ruf Amin who at that time was Chairman of the Assembly Indonesian Ulema (MUI) attended the gathering.

The results of the Muslim political communication as previously explained were the trial of Ahok and a sentence of 2 years imprisonment for blasphemy against religion. It seems that the purpose of this political communication succeeded in realizing their goal of imprisoning Ahok. However, this result is a lesson for the government to no longer accommodate the demands of Islamic groups. The 212 actions in 2016 continued on 2 December 2017 and 2018 with a fewer clear agenda but it can be assumed that the aim of the 212 of 2018 Action was to prevent Jokowi from becoming President for the second term. Later this action is named 212 Reunion.

Indonesia is a country with the largest Muslim majority population in the world. Indonesian Muslims can be categorized as moderate Muslims, namely Muslims who do not insist on applying Islamic Law (Sharia) as a state law but a compilation of Islamic law and secular law. Since the beginning of independence, Islamic groups have always considered minority's interests, for example by being willing to erase the 7 words of number one of Pancasila as the state ideology that reads Believe in One Almighty God by carrying out Islamic law for its adherents to become only "Believe in One Almighty God ". Therefore, the role of Muslims in the transition from an authoritarian political system to a democratic one is very significant. As mentioned by Anwar "The acceptance of religious, social and political pluralism by the 
Millatī, Journal of Islamic Studies and Humanities, Vol. 5, No. 1, June 2020: 34-50

majority of Indonesia who is predominantly Muslim is clearly a key to Indonesia 's successful transition from authoritarianism to a pluralist democracy"

The Indonesian Reformation Era of 1998 brought expectation for better democracy when freedom of the press and any other democratic institution was introduced into the Indonesian political system that makes Indonesia a third democratic state in the world after The US and India. However, democracy tends to be deteriorating under Jokowi compare to the first decade of the reformation era. This tendency can be noticed from the report of Economist Intelligence Units (2018) democratic Index ${ }^{5}$. It indicated that media remains substantially less free and pluralistic than it was during the first decade of reformation ${ }^{6}$. Although Jokowi was benefited from the development of digital technology and democratic system of government during his Jakarta's governmental and national Presidential election, he restricted the freedom of the press at the end of his first Presidential term.

After The 212 Action that succeeded in imprisoning Ahok, the Jokowi regime appeared to be more cautious towards Islamic groups, especially against FPI and the GNPF-MUI which were considered to be hard-liner Muslims. Furthermore, the way this regime accommodates the interests of Islam is to recruit certain Islamic groups namely NU, and put aside or even exclude considerations of accommodation in the political system.

The application of unequal policies towards Islamic groups has resulted in divisions and mutual suspicion among fellow Muslims. Islamic groups that are considered often oppose or criticize government policies are considered radical Islam, anti-Pancasila, anti the Republic of Indonesia (NKRI), and supporters of the Khilafah or the Islamic political system. FPI is regarded as one of the hard-liner groups that meet with those opposition's criteria and therefore its leader, Habib Rizieq, has been banned from returning to Indonesia, living in political exile in Saudi Arabia since 2017.

This policy is an effort to weaken the opposition less democratically. Despite this Action 212 continued until 2018 and 2019, but the mass media did not cover it. There are two reasons why the mass media are not willing to cover 212 Reunion Actions in 2018: First, because of

\footnotetext{
${ }^{4}$ Dewi Fortuna, Anwar, "Foreign Policy, Islam and Democracy in Indonesia", Journal of Indonesian Social Sciences and Humanities, Vol 3, (2010): p. 43.

5 Thomas P. Power, “Jokowi's Authoritarian ...", p. 307-338

${ }^{6}$ R. Tapsell, Media Power In Indonesia, Oligarch, Citizens And The Digital Revolution (New York, Toronto, Plymouth (UK): Rowman \& Littlefield International Ltd., 2017).
} 
the government's attitude which encourages the media not to cover this news for political stability as said by the former Chairman of the National Intelligence Agency ${ }^{7}$. Covering FPI's activities and the news about the coverage of Habib Rizieq would disturb national political stability. Second, because the objectives of the Action in 2018 and 2019 were unclear, and suddenly emerged symbol of the 2019's Change the President. Therefore, the media are no longer interested in covering events that are regarded as no longer valued as news. Although changing the facts to be news is the main task of mass media.

There was an attempt by Jokowi to articulate and aggregate the interests of Muslims by electing Amin Ma'ruf as vice-president. Ma'ruf was previously the Chairman of the NU which is the largest Islamic organization in Indonesia and the Chair of the MUI which is an Islamic Institute that accommodates all the interests of Muslims from various groups. However, some Islamic groups and organizations are still not satisfied with this choice considering that Ma'ruf Amin has no experience at all in managing domestic and foreign politics. By the age of 76, will Ma'ruf be able to assist the President in managing 276 million people and managing 5 million square kilometers of Indonesian territory? This choice tends to be political to collect votes (votes gather) rather than professionals for the benefit of the country. There is concern about what if Ma'ruf replaces the President's address before the UN General Assembly when Jokowi is always absent to attend. All public concerns about Ma'ruf Amin's choice to become Vice President for the second term of the Jokowi Presidency were packaged by the media as the right choice for the country. The media has succeeded in reconstructing the facts in the interests of the incumbent President subjectively. This tendency raises the suspicion that the media is never neutral in conveying the facts and even tends to be biased. What is reported depends very much on the partisanship of the media, who gets what to say, to whom.

On the other hand, media is one important element in political communication. As Mc Nair said: "which brings us to the third element in the political communication process-media organizations which today comprise print, broadcasting, and online channels. Freedom of the press for the media is a guarantee for democracy in the political system. Political actors can use the media to convey their political messages to the intended object (audience), convey policies, for government and community campaigns, or to convey demands from the public. After the end of the

\footnotetext{
7 See: Tribune News, December $4^{\text {th }} 2019$.

${ }^{8}$ Brian Mc Nair, An Introduction to Political..., p. 14.
} 
Millatī, Journal of Islamic Studies and Humanities, Vol. 5, No. 1, June 2020: 34-50

Authoritarian regime, Indonesia entered an era of democratization, one of which was marked by the freedom of the Press which gave hope to political actors to deliver their political messages in a democratic way. However, it turns out that Media Indonesia is dominated by media Oligarchy. If political Oligarchy is defined as a form of government controlled by a small group of people, then Oligarchy Media is a media controlled by a small group of people.

The impact of media oligarchy is quite significant for democratic life in Indonesia such as; public distrust of the media, the news delivered in favor of certain groups, prioritizing the interests of the owner, biased news, media owners become interested in engaging in politics so that the media loses its function to maintain and control the course of democratic governance. It is believed that understanding contemporary Indonesia should understand how media oligarchy works. Tapsell states that media oligarch groups emerged under a political system controlled by New Order oligarchs and Indonesian laws are not strict enough to limit media ownership concentration?

Indonesian oligarch media are Indonesian media owners who enter the Television business first and then print media. Some of the media that emerged in the Reformation era were: Trans TV owned by Chairul Tanjung, an Indigenous Muslim; RCTI (Rajawali Citra Indonesia) and Global TV owned by Harry Tanusoedibjo, a Christian of Chinese descent who later developed the Media business into MNC TV (Multy National Corporation) which later became the largest Media TV in Indonesia by developing Indonesian Cable TV Indovision; Indosiar and SCTV owned by Edy Kusnadi Sariiatmaja; TV One and ANTV (Andalas TV) owned by Abu Rizal Bakri, former Chairman of the Golkar Party, the ruling party of the New Order era; Metro TV owned by Surya Paloh, a member of Golkar Party; KOMPAS TV owned by Jacob Oetama, Christians and founder of Indonesian leading Newspaper KOMPAS; NET TV owned by Wishnutama. In addition to having a TV Station, they also dominate newspaper ownership: RCTI has Sindo newspaper; Metro has Media Indonesia; KOMPAS TV has KOMPAS Daily, and Republika is the only Muslim Newspaper founded by Association of Islamic Scholar (Ikatan Cendekiawan Muslim Indonesia) but later Erick Thohir holds the majority of ownership share.

\footnotetext{
${ }^{9}$ R. Tapsell, Media Power In Indonesia..., 2017.
} 
Political development is less democratic when Mass Media is dominated by minorities, and the government does not limit or regulate media ownership so that one person can own several media such as Harry Tanusudibjo who has more than 3 media. The Indonesian media oligarchy is largely owned by non-Muslims who often do not articulate or aggregate the interests of Muslims. In the next development, the media owners then established parties such as Harry Tanoesudibjo who founded the Perindo Party (Indonesian Party) and Surya Paloh who founded the Nasdem Party (National Democratic Party). The tendency of all parties established by the media owners is to support President Jokowi so that they do not broadcast news that might harm the incumbent president.

The relationship between Media Oligarchy and politics has been very palpable since the 2014 presidential election. Many have argued that President Jokowi's victory was greatly benefited by the media who exposed Jokowi's good image who lacked political experience, especially foreign policy. The issues raised by the television station are very dependent on the interests of the owners and the competition between them. The Jakarta Bay reclamation problem, for example, is strongly supported by Metro TV owned by Surya Paloh who later supported Jokowi from the Indonesian Democratic Party of Struggle (PDIP-Perjuangan). On the other hand, TV One which is owned by Abu Rizal Bakri opposes the reclamation of Jakarta Bay.

Another case is the issue of 212 Reunion in December 2018 when millions of Muslims gathered in one place in peace which is the focus of this article. All television stations did not cover this news except TV One, which covered from the beginning before dawn until sunset. This peaceful action is very important for Indonesian Muslims to respond to the accusation that the majority of Indonesian Muslims are radical, anti-state ideology, and the anti-unitary state of Indonesia. These two examples show that media oligarchy has succeeded in constructing facts that are considered news because there are a business and political interests. While the public expects that there is news based on the actual facts and explaining what happens behind the facts.

It is generally accepted that in the democratic type of government the majority rules. By definition, this means the greater number should exercise greater power. However, this principle is inapplicable in Indonesia even though at least $87 \%$ of the population is Islam, they are powerless. The 212 Reunion Movement is an assembly of the majority to voice injustice 
Millatī, Journal of Islamic Studies and Humanities, Vol. 5, No. 1, June 2020: 34-50

perpetrated by those in power who are really heavily supported by minorities. The 212 Reunion Movement was the Muslim's ultimate forum to campaign Islam as the religion of peace as they are unable to rely on the impartial press or mass media. The gathering of millions of Muslims at the National Monument Square is gathering to defend Islam as we are the recipient of injustice. While the media described the gathering as a demonstration of intolerance the living proof indicates otherwise. It is a nonviolent gathering that symbolizes the solidarity of Muslims in Indonesia. The main purpose of the gathering shows to pray for Indonesia to be a better place to live, and united as a nation, although we are culturally diverse.

The pattern of Indonesian political communication in the reform era especially under Jokowi has always been colored by the dominance of the state-supported by the Indonesian media oligarch. As a result, the media cannot be neutral and lose their function as a media to bridge communication between the government and the people and vice versa. This situation has led to the potential for conflict between the government and the community, especially the Islamic community, perpetrators and supporters of Action 212. Moreover, they have determined that they will carry out Action 212 by mobilizing the masses every year with a demanding agenda tailored to the circumstances. The government should have a political strategy to accommodate the interests of Muslims if not their legitimacy will be threatened.

\section{CONCLUSION}

On the basis of Gabriel Almond's theory, it can be concluded that the main function of political communication carried out by the media is to support the government to make rulemaking, rule application, and rule adjudication by facilitating political socialization, articulation, and aggregation of interests. When the function of political communication is ignored by stakeholders, the country's democracy will be threatened. Freedom of the press as a symbol of the functioning of democracy must be interpreted as the freedom of the people to obtain accurate news without endangering public order. Even though Muslims are the majority in Indonesia, but because the mass media is controlled by a minority, it is very difficult to expect their interest to be exposed by the media. Media will preach news that benefits the interest of their owners. 


\section{REFERENCES}

Anwar, Dewi Fortuna. 2010. "Foreign Policy, Islam and Democracy in Indonesia". Journal of Indonesian Social Sciences and Humanities. Vol. 3. Pages 37 - 54.

Efendi, G, Manayang, V and Hidayat. Januari 2009. "Political Communication in Indonesia". Article uploaded.

Fukuyama, Francis. 2018. Contemporary Identity Politic, and The Struggle for Recognition. Profile Books Ltd: London

Jackson, Karl D, and Pye Lucian. 1978. Political Power and Communications in Indonesia, University of California Press: Berkeley, Los Angeles. London.

James, E., and Alvey. 2005. "Economic and Religion, Globalization as the Cause of Secularization as Viewed by Adam Smith". International Journal of Socials Economics. Vol. 32, Number 3.

Ibnu Rejo, S. 2015. "Komunikasi Politik Kontemporer Indonesia”. Jurnal Ilmu Pemerintahan, CosmoGov. Vol. 1. No 2.

Yusuf Al Fatih. 2017. "Bagaimana Komunikasi Politik Indonesia? (How Indonesian Political Communication)”. RILIS.ID. February 14, 2017. 02.21 Western Indonesian Time.

Kersten, Carol. 2017. A History of Islam in Indonesia: Unity and Diversity. Edeinburgh University Press: Edinburg.

Mc Nair, Brian. 2011. An Introduction to Political Community. Routledge: London, New York.

Mietzner, Marcus. 2009. Military Politics, Islam, and the State in Indonesia: From Turbulent Transition to Democratic Consolidation. ISEAS Publication: Singapore.

Power, Thomas P. 2018. “Jokowi's Authoritarian Turn and Indonesia's Democratic Decline, Pages 307 - 338, Published on line 11 December 2011,

Thomas P. Power. 2018. "Jokowi's Authoritarian Turn and Indonesia's Democratic Decline”. Bulletin of Indonesian Economic Studies. Vol. 54. Issue 3. Pages 307-338, 
Millatī, Journal of Islamic Studies and Humanities, Vol. 5, No. 1, June 2020: 34-50

https://www.tandfonline.com/doi/abs/10.1080/00074918.2018.1549918?journalCode $=$ cbie 20 .

Prabowo, E, Sulismadi and Safri. 2017. "Theoretical Review of Political Communication and Political Achievement Strategy". International Journal of Management and Administration Sciences (IJMAS). Vol. 4. No. 04. Pages 22-30.

Rumadi. 2015. Islamic Post-Traditionalism in Indonesia. Yusof Ishak Institute: Singapore

Sen, Krishna, and Hill, David T. 2001. Media, Budaya dan Politik Di Indonesia. PT Media Lintas Inti Nusantara: Jakarta.

Sofjan, Dicky. 2016. "Religion, Public Policy and Social Transformation in Southeast Asia, Managing Religious Diversity". Globetthics.net International Secretariat: Geneva, January 2019.

Susilowati, Ida, et al. 2019. “Politics Identity on Great 212's Reunion”. Dauliyah. Vo. 14. No. 1.

Susanto, EH. 2013. Komunikasi Politik, Pesan, Kepemimpinan dan Khalayak (Political Communication, Leadership and Public). Mitra Wacana Media: Jakarta.

Thantowi, PU. 2012. "Religiousity, Parties and Election: Islamization and Democratization in Post Soeharto Indonesia”. Indonesian Journal of Islam and Muslim Societies. Vol 2. Number 1. June 2012. Pages $1-27$.

Wolfsfeld, Gadi. 2011. Making Sense of Media \& Politics: Five Principles in Political Communication. Routledge: New York.

Subiakto, H. and Ida R., 2012. Komunikasi Politik, Media dan Reformasi. Prenada Media Group: Jakarta.

Tapsell, R. 2017. Media Power In Indonesia, Oligarch, Citizens And The Digital Revolution. Rowman \& Littlefield International Ltd: New York, Toronto, Plymouth (UK). 